\title{
11 Standing together in faith through the time of COVID-19
}

\author{
The responses of Church \\ umbrella bodies in Zambia
}

\author{
Nelly Mwale and Joseph Chita
}

\section{Introduction}

The global outbreak of COVID-19 which was first reported in Wuhan, China and in Zambia on 18 March 2020 affected all spheres of life including religious communities. While the interaction of religion and the pandemic attracted media attention, religion and public health interface continued to receive limited scholarly attention. This was despite the fact that religion manifested its presence in public health not only as a provider of healthcare, but as part of the emergency response team. The immediate scholarly engagement with COVID-19 in the country was grounded in education as Sintema (2020), Mulenga and Marbán (2020) focused on the effect of the pandemic on the performance of Grade 12 learners with reference to STEM subjects and COVID-19 as a gateway for digital learning in Mathematics education, respectively.

This chapter focuses on the place of religion in the COVID-19 pandemic as exemplified by the Church umbrella bodies in the country. It specifically addresses how Church umbrella bodies responded to COVID-19 in relation to emerging solutions, challenges and suggestions in the early phases of the pandemic in Zambia. This was deemed significant in a context with a multi religious landscape which implied that people's orientation to public health messages was, by and large shaped by religious beliefs and the response of the religious leaders.

Given that COVID-19 was a new pandemic, the chapter sought to not only indirectly contribute to the discourses of religion and public health in Zambian scholarship that has been preoccupied with other pandemics, but also take stock of religion's complex role during pandemics and consequent contribution during a crisis. Acknowledging that different religious actors were involved in the fight against COVID-19, the interconnectedness of religion and public health in Zambia during the COVID-19 pandemic is purposively situated in the institutional setting of the Christian umbrella bodies, commonly referred to as Church Mother bodies. This is because although the Zambian religious landscape is multireligious (with representation of other religions like Islam, Hinduism, Zambian Indigenous Religions, Bahai 
and Sikhism which account for smaller percentages in terms of following), Christianity remained the dominant religion. Zambian Christianity is often spoken of as represented by the Church umbrella bodies. These are the Zambia Episcopal Conference (ZEC), now the Zambia Conference of Catholic Bishops (ZCCB), the Council of Churches in Zambia (CCZ), the Evangelical Fellowship of Zambia (EFZ), Independent Churches Organisation of Zambia (ICOZ) and the Bishops Council of Zambia (BCZ).

Officially instituted in 1963, the ZEC [ZCCB] is the administrative body of all Roman Catholic dioceses (Hinfelaar, 2004) and member of the Association of Member Episcopal Conferences in Eastern Africa (AMECEA) and Symposium of Episcopal Conferences of Africa and Madagascar (SECAM). The CCZ was established in 1945 as the umbrella body of mainline Protestant churches. The EFZ was officially formed in 1964 to oversee evangelical churches. In 2001 a fourth umbrella body, ICOZ, was formed to bring together charismatic churches, ministries, fellowships, and centres. The latest Pentecostal Church umbrella body is the BCZ.

The involvement of religious actors in public health was not new in Zambia. Apart from religious institutions forming the bulk of the health delivery systems as part of national health service delivery, the Church umbrella bodies have often collaborated on different fronts in health related ventures. For example, in the wake of HIV and AIDS, the umbrella bodies partnered with other religions to form the Zambia Interfaith Non-Governmental Organisation (ZINGO). The Church umbrella bodies were also key actors during national epidemics like cholera. For example, during the recent cholera outbreak of 2017 that was declared by the Ministry of Health $(\mathrm{MoH})$ on 6 October 2017, with 547 cases of which 15 deaths were recorded with a case fatality rate of $1.8 \%$ (WHO, 2017), the Church umbrella bodies were part of the response team. With the underprivileged living in poorly serviced communities mostly affected by cholera, the majority of this population was served by both religious bodies and government.

With a background of engagement in pandemics and epidemics, it became imperative to understand the responses of the Church umbrella bodies during the COVID-19 outbreak. The chapter unfolds by situating the responses of the Church umbrella bodies in existing scholarship, highlighting the context of COVID-19, approach to religion and public health and research design before exploring the responses of the Church umbrella bodies to the pandemic.

\section{Religion and pandemics in existing literature}

The chapter situates the responses of the Church umbrella bodies to COVID-19 in discourses of religion and pandemics, especially that which is centred on religious or faith leaders. This scholarship has partly engaged with the role of religious leaders in curbing pandemics. For example, with reference to Cholera, Braley (2017) drew on the history of the 1854 cholera epidemic in London to highlight how histories of cooperation between 
religion and public health could help focus thinking about the potential for intersectoral cooperation in response to modern epidemics concluded that responses to contemporary epidemics continued to involve local religious entities and global religious networks.

In the case of Ebola, Jansen (2019) concluded that the unified voice and collective action from faith leaders around infection prevention activities decreased the fear and stigma about Ebola. This was through the religious leader's communication of messages of hope to the population. Jansen observed that the Muslim and Christian faith leaders drew lessons from their own religious texts to support the recommended infection control and prevention measures for Ebola. These included seeking medical care when sick, avoiding contact with bodily fluid, and routine hand washing after contact with the sick or with dead bodies. Faith leaders emphasized the need for safe and dignified burials, acceptance and appreciation of Ebola workers and validated the need for psychosocial support for those impacted by the disease, rather than stigmatising them.

Similarly, with reference to the Ebola outbreak in 2014-2015 that profoundly disrupted three west African countries (Guinea, Liberia, and Sierra Leone), Marshall and Smith (2015) also recognised that religious beliefs and practices shaped (positively and negatively) ways of caring for the sick, patterns of stigma, and gender roles and affirmed that throughout the crisis, religious institutions provided services including health, education, and social support.

With regard to COVID-19, emerging scholarship has also been centred on religion's role in the spread of the pandemic and religion's response to the pandemic. For example, Jala et al. (2020), while focusing on social distancing, examined how religion, culture, and burial ceremonies undermined the efforts to curb COVID-19 in South Africa. They observed that during funeral rites, social distancing was not necessarily followed while cultural practices (such as those relating to washing of hands in one basin after the funeral) presented an opportunity for guests to contract the virus. Using the context of Nigeria, Tanzania and Ethiopia, Lichtenstein et al. (2020) also observed that while many religious leaders had complied with government regulations and policies, others had spread religious ideology and doctrine supporting the notion that faith or belief would protect one from the virus. Similar conclusions were drawn in South Korea (Wildman et al., 2020).

The focus on COVID-19 and religion in emerging scholarship has also been on the positive responses of religion through mediatisation in addressing the pandemic. For example, Aluko (2020) from the Nigerian context analysed the various responses of the Christian denominations to the emergence of the COVID-19, and subsequent lock down of the whole country. Aluko observed that some churches devised a means of worshipping through the services provided over the Internet (such as streaming their services online), through the use of Facebook, WhatsApp, YouTube, Instagram, Twitter, Mixlr, Zoom and Vimeo among others. Wildman et al. (2020) also concluded that most religious groups were innovating in response to 
opposing demands of collective worship and social distancing by conducting online services, stretching the world's data bandwidth at certain times of the week to stream live videos of suitably modified rituals, sermons, and prayers, including disseminating practical health information and offering urgent financial help in the wake of rapidly degrading economic conditions.

Similar observations were made in the Philippines context, where Catholic congregations took steps to provide the public with online-based Church masses, community prayers, spiritual recollections and retreats and eucharistic adoration and processions, including people dealing with issues about mortality, coping and recovery were provided via online formative counselling and pastoral guidance (del Castillo et al., 2020).

While acknowledging the complex role of religion during pandemics, the foregoing studies affirm how pandemics can be positively or negatively shaped by religion and religious actors in different contexts. However, the responses of religious leaders to the pandemic in the Zambian context were yet to receive scholarly attention, thus this chapter seeks to contribute to emerging scholarship on religion and COVID-19 with specific reference to the Church umbrella bodies in Zambia.

\section{Brief context of COVID-19 in Zambia}

First reported on 31 December 2019, in a wet market in Wuhan, China, it became a global threat as cases of the virus were confirmed in numerous countries and territories worldwide. The WHO consequently declared the disease as a pandemic on 11 March 2020.

In Zambia, the first reported cases were a couple that travelled to France for a short holiday. The two cases were announced a day after the Government of the Republic of Zambia (GRZ) announced the shutting down of all educational facilities as a preventative measure against the pandemic. Since 18th March 2020, cases of the COVID-19 were on the increase. The hot spot was initially Lusaka, the country's capital, before the pandemic soon spread to other parts of the country such as Nakonde in Northern Zambia, the Copperbelt, North-Western, Muchinga and Southern provinces.

According to the $\mathrm{MoH}$, as of 27 May 2020, the country had recorded 1,057 confirmed cases, 779 recoveries, seven fatalities and 271 active cases $(\mathrm{MoH}$ Ministerial update, 27 May 2020). To prevent the spread of the disease, measures such as social distancing and lockdowns in certain towns were implemented as supported by the Public Health Act Cap 295 of the Laws of Zambia through two statutory instruments (SI) 21 of 2020 which designates COVID-19 as a notifiable disease and SI 22 of 2020 which provides additional regulations to facilitate management and control of COVID -19 (MoH, 17 March 2020). The outbreak of the pandemic had diverse impacts on the well-being of people. For example, besides the socio-economic impacts, the pandemic took a toll on people as they underwent different forms of suffering such as sickness, dying and death, grief and mourning among other aspects. 


\section{Analytical lens: approach to religion and public health}

As shown in the selected existing literature on religion and pandemics, the response of religion to public health, particularly pandemics, is not new in scholarship. For example, besides the role of religion in the Cholera and Ebola outbreaks, religion was also identified as one of the multifaceted approaches through which the HIV and AIDS pandemic could be addressed as shown by different scholars (such as Iyakaremye (2015)).

In linking religion and other spheres like health, different approaches to religion are used, the most popular being aligned to notions of religious assets. For example, the African Religious Health Assets Programme (ARHAP) identified religious assets for addressing health matters expressed in six assumptions, some of which include the wide presence of Faith-Based entities on the ground in many contexts where health crises are most urgent and having a public impact on health (ARHAP, 2005:2). Thus, the intangible and tangible religious health assets include infrastructure; funding agencies and healers; prayer; health seeking behaviour and relationship for care; choirs, rituals and leadership skills and faith, time, and power as identified by scholars like Olivier (2011) and Chitando (2007) among others.

These perspectives are closely related to notions of religious capital as expounded by Verter (2003) who offered a model of religious capital. Verter's (2003) 'spiritual capital', included religious knowledge, competencies, and preferences as 'positional goods' within a competitive symbolic economy. Religious capital relates to the skills and experiences specific to one's religion including religious knowledge, familiarity with ritual and doctrine and friendliness with fellow worshippers (Iannaccone, 1990). This perspective takes the view that capital also exists in symbolic forms (Verter, 2003). Similarly, ter Haar's notion of religious resource can be closely related to these concepts of religious assets and religious capital. Religious resources consist of ideas, practices, organisation, and experiences (ter Haar, 2005).

Given the interconnectedness of concepts of religious assets, capital, and resource, the chapter links religion and public health through the concept of religious resource. In doing so, this chapter takes the view that religion through its resources that are located in the ideas, practices, organisation, and experiences could be deemed significant to understanding the responses of the Church umbrella bodies to COVID-19 pandemic especially as expressed by the religious leaders. It acknowledges the constructive and destructive tendencies inherent in religion as a social construct with the potential to be used positively or negatively during any pandemic. Indirectly, the religious resources are linked to theological perspectives that have emerged as tools for religion's response to pandemics especially the theology of life (Dibeela, 2007), compassion (Dube, 2007), and healing (Hadebe, 2007).

\section{Research design and methods}

The chapter draws on insights from an interpretative case study because there was little known in a particular research area (Barker et al., 2002), and 
that the interest was to explore in depth the responses of the Church umbrella bodies to the COVID-19 pandemic. The primary method of data collection was content analysis, which included institutional reports, postings, and newspaper articles in the public sphere. Given that non-probability sampling is more appropriate in interpretative case studies (Kothari, 2004:56), the Church umbrella bodies were purposively selected as the case study was situated in an institutional context.

Similarly, the avenues for data were purposely selected. Limiting the notion of media to its technological uses in which the media was a conduit for the transmission of messages from religious leaders in the face of COVID-19, the content analysis was situated in different forms of media, such as television, newspapers, and photographs in the public space. Since social media was an area of research, just as religious websites were dynamic archives of religious worlds (Hackett et al., 2014), it was used as a supplementary source of data. The data were collected between April and May 2020.

The collected data were inductively analysed using the general framework for interpretive qualitative research suggested by Elliott et al., (1994). In this case, the data were thematically analysed through a search for common themes that transcended the data alongside an interpretation of the themes. This involved the generation and application of codes to the data, and the identification, analysis, and report of patterns (themes) (Braun and Clarke, 2006:77-101).

\section{Response of Church umbrella bodies to COVID-19 in Zambia}

The Church as a part of societal structures not only recognised that it was impacted by COVID-19, but also positioned itself as a tool in navigating through the pandemic by way of providing some solutions during the crisis.

\section{Solutions offered by the Church umbrella bodies during the pandemic}

The Church umbrella bodies contributed towards providing solutions through their response to the pandemic. This was largely by offering solidarity through: Suspending public worship; offering public health education and service provision; pastoral care and advocacy so as to address different forms of suffering resulting from the pandemic.

\section{Offering solidarity in the fight against the pandemic}

The Church umbrella bodies recognised the dangers associated with the pandemic in the country.

As Church of our Lord Jesus Christ, we understand the effects of this outbreak on the people of Zambia and the world at large. We liken this scenario to that found in the Gospel according to Matthew 8:23 where the storms hit the boat on which the disciples were, while Jesus Christ 
was asleep on the same boat. The storms were very strong and almost overpowered the boat. But the disciples knew who was with them in the boat and they cried out to him and he woke up and rebuked the storms. We wish to encourage everyone that we will be secure because there is hope in the Lord; we will take our rest in safety (Job 11:18).

(Church Mother Bodies Statement, 28th March 2020)

As such, the Church umbrella bodies called for unity of purpose among Zambians in an effort to address COVID-19. This was through a joint press briefing at the Catholic Secretariat at Kapingila House in Lusaka where they also pledged to work with the government in the fight against the pandemic.

Zambia Conference of Catholic Bishops (ZCCB) and other Church Mother bodies have called for unity of purpose among Zambians in an effort to address COVID-19. The ZCCB, Evangelical Fellowship of Zambia and Independent Church of Zambia at a joint press briefing held at the Catholic Secretariat at Kapingila House in Lusaka on the 28th of March, 2020, pledged to work with government in the fight against Coronavirus.

(Mukuka, AMECEA News, 3rd April 2020)

By pledging to offer solidarity and support to the government during the COVID-19 pandemic, this did not mean that the Church umbrella bodies were always in support of government as they had often critiqued the government on numerous national issues as was the case on the recent closure of the private TV station (Ncube, News diggers, 7 March 2020).

The Church umbrella bodies also called for stringent measures to control the spread of the pandemic such as calling for a lock down.

We are privy to the fact that this move will negatively affect our economy but given the current scenario, we do not have a choice but to close all our borders in order to preserve human life. In addition to closing borders, we also advocate for a shutdown of all public gatherings and stringent measures to limit physical contact in markets, bus stations and restricting numbers in public transport vehicles.

(Chisanga, Mast Newspaper, 29th March 2020)

As observed by the General Secretary of CCZ, the Zambian churches collaborated in response to COVID-19 through issuance of "pastoral statements to the nation calling for the church to follow and abide by government guidelines regarding the fight against COVID-19' (Fr. Emmanuel Yona Chikoya, May 2020). The Church umbrella bodies' response through offering solidarity during the pandemic is line with conclusions by Deguma et al. (2020), that different Catholic congregations were in solidarity with the poor by drawing on the Catholic Church's Social Teachings which resonated with 
the Liberation Theology' of Gustavo Gutiérrez in the Philippines in their responses in mitigating the experience of the crisis among Filipino poor amid COVID-19 pandemic. As observed by O'Brien and Shannon (1992:421), solidarity entailed persevering determination to commit oneself to the common good; that is to say, to the good of all and of each individual, because we are all really responsible for all.

\section{Suspending public physical worship}

Apart from pastoral statements, the Church umbrella bodies practically undertook preventive measures as informed by $\mathrm{MoH}$ and $\mathrm{WHO}$ guidelines on the pandemic. These included holding an online national prayer on 29 March 2020 as opposed to physical prayers. The Church umbrella bodies held a National Day of Prayer and fasting under the theme "standing together in faith through the times of the coronavirus".

During this National Day of Prayer and fasting, people were advised to fast and pray in the comfort of their homes as no gathering would be held in any church for the prayers. The National Day of Prayer was aired on the national TV while other churches conducted their church meetings online as a preventative measure to address the virus.

(ZNBC TV News, 29th March 2020, 19:00 GMT)

Thus, faith became a uniting force amid the pandemic through which religious communities readily engaged in acts of solidarity that built community resilience. The national online prayers were accompanied by suspending church gatherings.

We wish to inform the nation that as Church Mother bodies we have instructed all our membership across the country to be proactive and channel all energies in preventing the spreading of the disease. Given the rising numbers of confirmed cases of COVID-19 in Zambia, we have resolved to suspend Church gathering for at least 14 days. For some Church Mother bodies, this will take effect on Sunday 29th March 2020 while for others the commencement date as already communicated will be Monday 30th March 2020.

(Church Mother Bodies Statement, 28th March 2020)

Even after the Presidential directive that places of worship could reopen after a month of lock down (Presidential address, ZNBC TV 24 April 2020), the Church took a stance to maintain the closure of their churches. The churches directed their members to await further communication from the Church leadership. For example, the ZCCB leadership emphasised that no 'mass or service' would take place:

the suspension of all public church gatherings and communicable liturgical celebrations will remain in effect... In the meantime, the Church 
remains desirous of protecting the lives and health of its members and pastoral agents. Allow me to exhort you to religiously and judiciously follow the rules of hygiene especially those of washing your hands with soap regularly, and thoroughly; avoiding physical greeting and contact; observing social distancing; avoiding to touch your eyes, nose and mouth; avoiding to spit in public; covering your mouth and nose with a bent elbow or tissue when coughing or sneezing and wearing face masks whenever you are in public...Once more give heed to the extortion of St. Paul; we must never get tired of doing good because if we don't give up the struggle, we shall reap our harvests at the proper time (Galatians 6:9).

(ZCCB Memo, 25th April 2020)

Other Church umbrella bodies also reacted in the similar manner. The rituals of death, mourning and burial were also limited to few people so as to manage the pandemic. This response signified the authority of the religious actors and concern for safety of the people during the pandemic. This was significant given that in other contexts, the spread of the pandemic was linked to church gatherings (Wigglesworth, Los Angeles Times, 24 May 2020). The Church umbrella bodies' suspension of public worship was consistent with how other faith leaders had responded to the pandemic as concluded by Aluko (2020), Wildman et al. (2020) and del Castillo et al. (2020) among others. This was also similar to how the Church had responded to the cholera outbreak by suspending some religious rites as affirmed by Becket (2018) and Mwale and Chita (2020) that Catholics were advised to stay away from funeral houses as only a priest could go there for prayers.

\section{Public health education and service provision}

Besides reorienting Church operations, the Church umbrella bodies further responded by providing public health education on the pandemic. The Church umbrella bodies also instructed their members to adhere to preventative messages.

Adhere and follow all instructions and guidelines being shared by the government and other authentic stakeholders and pray for God's intervention. It was time that science and gospel worked together to save the world from calamity. Encourage people to go for medical attention while you pray for them. Avoid telling your members to depend on prayer alone. Let them get both prayer and medical attention from health facilities. The Church must avoid being an obstacle in the fight against the spread of the coronavirus disease.

(Church Mother Bodies Statement, 28th March 2020)

Additionally, the mother bodies provided medical facilities and financial and material resources towards the fight against the pandemic. CCZ offered their structures (David Livingstone College of Education) to be used as quarantine facilities by the government; and like other Church mother 
bodies led the way by stopping large gatherings, changed the way of worship and how religious rites were conducted; offered food and other necessities to the very vulnerable families (aacc-ceta.org, 2020). Similarly, the ZCCB were involved in setting up a COVID-19 Response Fund (CRF). CRF was meant to fund prevention programmes in Zambia and to offer support to 59 health facilities working to curb COVID-19 in the ten Provinces of Zambia (Agenzia Fides, 2020). This was accompanied by pastoral care within the context of the pandemic by emphasising that physical distancing did not mean spiritual isolation and pledging to help provide pastoral care to communities especially the vulnerable, the dying and bereaved, the elderly and psychologically distressed. This demonstrated that the Church bodies were not only playing their prophetic role through issuing press statements and pastoral letters but also through service delivery and programmes.

The Church umbrella bodies' responses resonated with the manner in which the Church umbrella bodies had responded to the cholera and HIV and AIDS crisis and therefore affirmed faith leader's role in relying preventative messages and providing service during the pandemics (Featherstone, 2015; Marshall, 2016). Additionally, the responses of the Church umbrella bodies were related to Mendoza (2020)'s observation from the Philippine context in which the pandemic was seen as a trying time which called the Church to move by doing concrete acts of charity by sharing resources with those who need it the most. Similarly, Deguma et al. (2020) affirmed that through putting its social teaching into practice, the Church was not only for the poor but more substantially, a Church of the poor and by preferring the poor, the Church strengthened the whole community by assisting those who were the most vulnerable.

\section{Advocacy and call for accountability}

The Church umbrella bodies further advocated for the wellbeing of the poor by urging the government to give priority to those who lived in poverty as well as the marginalised and refugees living in the country.

We urge the government to come up with mechanisms such as economic stimulus packages and mitigating measures as well as incentives to help the industry and citizens in coping with the adverse effects of the Coronavirus.

(Chisanga and Chisenga, Mast Newspaper, 29th March 2020)

The stance by the Church umbrella bodies to advocate for the plight of the poor resonates with the observations (with reference to) of the Catholic Church made by Phiri (1999) that ZEC challenged the government to look into the plight of the poor,

the Church cannot be silent in the face of this suffering of our people. The word of God challenges us: 'If you refuse to hear the cry of the poor, your own cry for help will not be heard' (Proverbs 21:13). 
The advocacy for the poor was also accompanied by calls for accountability on COVID-19 resources. In this regard, they urged the government to ensure that there was proper stewardship and accountability of all donations and allocated funds for the COVID-19 control programme. This was similar to the Philippines context in which the pandemic was viewed as another oppressor of the poor as it slowed down the economic sector and the poor bore the brunt of the crisis (Mendoza, 2020), thus the Church had to safeguard the interest of the masses by calling for accountability and transparency.

\section{The challenges and Nature of Church umbrella bodies' response to COVID-19}

The response of the Church umbrella bodies to COVID-19 revealed both the challenges that emerged during the pandemic and religion's potential to be used as a resource during a crisis. The challenges revolved around the themes of debates on the existence of COVID-19 and Pastoral care among the faithful, increased vulnerability of vulnerable groups, distress and limited health infrastructure.

\section{Debates on the existence of COVID-19 and pastoral care}

To start with, the Church bodies' response to the pandemic was characterised by the challenge surrounding the debates on the existence of the pandemic the country. Soon after the breakout of the pandemic and the introduction of the prevention and management measures, there were some expressions of doubts as to whether the pandemic was real or not, including non-compliance of the preventative measures. For example, the UN Office for the Coordination of Humanitarian Affairs (2020) observed that poor compliance by the public to recommended prevention measures such as use of masks, hand hygiene and limited laboratory testing, remain key challenges to the COVID-19 response. This made the voices of the religious leaders significant as they urged the population to heed the advice from the medical practitioners (Church Mother Bodies Statement, 28 March 2020) and took a lead in following the guidelines on social distancing and stay home campaign by resorting to virtual worship among other measures.

The debates on the existence of COVID-19 in the country were also accompanied by misconceptions on how COVID could be prevented and managed. The Church umbrella bodies encouraged people to seek both medical and divine interventions during the pandemic. This could not be detached from the lessons and experiences they had gained over time in the country. This stance on approaching the pandemic with medical and divine intervention could also be easily linked to narratives of the HIV and AIDS pandemic in which people had abandoned Antiretroviral therapy in favour of prayers. Therefore, this guidance was posed to make a positive contribution 
at the onset of the COVID-19 pandemic. This is because social resistance to medical interventions had implications on the spread of infectious diseases, hence the Church umbrella bodies preached a message of linking science and religion by emphasising that it was time that science and gospel worked together to save the world from calamity.

Additionally, the response to the pandemic was associated with challenges relating to pastoral care in the moment of suffering. For example, the COVID-19 prevention measures entailed controlled rituals associated with sickness and death. This was a challenge given the nature of community as understood in the Zambian setting where for instance, one person's grief becomes a concern to every member of the community. Therefore, the limits posed on mourning and burial rituals remained the challenge the religious leaders and their communities had to deal with in the context of the pandemic. In this regard, the religious communities encouraged the community to reorient the way in which mourning was done by advising people to stay away from funeral houses as only a priest and religious officials could go there for prayers. This signified how religion was a resource, asset or capital towards navigating through the pandemic. This is because as opposed to using religion to frustrate the efforts to prevent and manage the pandemic, the Church umbrella bodies adhered to public health messages and took steps to provide leadership during the crisis. This was underpinned by the Church umbrella bodies' reinterpretation of their Christian dogma on worship to prevent and manage COVID-19 by suspending public worship and stressing that physical distancing did not entail spiritual isolation. These actions could not be detached from the teaching on human life as expressed by the Church Mother bodies. 'Our faith in the God of life compels us to protect life by doing all that we can to avoid transmitting this virus (Church Mother Bodies Statement, 28 March 2020). As observed by Muzaffar (2005), the transformative potential of religion lies in the shared spiritual and moral heritage of humankind.

\section{Increased vulnerability of vulnerable groups and distress}

The response to the pandemic was further characterised by the challenge of increased vulnerability of the vulnerable groups of people. For example, the lock down and stay home halted not only church gatherings but also businesses thereby worsening the socio-economic situation of the vulnerable. This explains the Church's stance to advocate for the well-being of the population. Closely related to the theology of life (Dibeela, 2007), the drive for the response also shows that the Church umbrella bodies continued to be compelled by their teachings on life. In so doing, they tapped into their role of reinterpreting religious ideas according to the social context which ter Haar (2005) argues is their prime responsibility. The Catholic social teaching that emphasised that while every person had a right to share in the benefits of the common good, everyone also had a right and duty to contribute 
one's share to the welfare of others, to the whole community, and even to the global community of humankind, especially the least well-off and most vulnerable (Cahill, 2007). The foregoing can easily be seen as a teaching shared among the Church umbrella bodies but also that which was related to the manner in which they responded to the pandemic. Thus, the responses were anchored on teachings on the option of the poor and vulnerable groups of society as COVID-19 had also revealed the long-standing inequalities entrenched in society. In a context characterised by high levels of poverty, the outbreak of the pandemic entailed that the poor would be negatively impacted, hence the religious leaders' concern for the poor.

The response of the Church umbrella bodies was also characterised by challenges of distress. The Church umbrella bodies used their scripture to provide hope to the people during the pandemic. By this, the Church bodies continued to be a source of meaning during the moment of grief and suffering. While this was part of the pastoral ministry of healing, this could be deemed significant during a time when people were filled with uncertainties. For example, through Bible passages like Matthew 8:23; Galatians 6:9, the Church provided assurance to their faithful in ways that pointed to their attempts to stand together in faith in the fight against the pandemic. The Church umbrella bodies' tapping into scripture during the crisis was therefore in line with conclusions drawn by scholars such as Jansen (2019) and Marshall and Smith (2015) during the Ebola outbreak. As observed by Marshall (2020), millions of people worldwide look more to religious authorities than health officials for guidance on how to behave and what to believe during a crisis.

\section{Health infrastructure}

Limited health infrastructure was another challenge in dealing with the pandemic. This was a challenge given that the health context of the country was already shaped by the burden of HIV and AIDS (the prevalence of HIV among adults aged $15-59$ was $12 \%(\mathrm{MoH}, 2019)$. The country's healthcare was the responsibility of state and non-state actors including Faith-Based Organisations (FBO). Challenges such as limited funds for health care, high burden of diseases and staff shortages, the rates of poverty, inequality and poor distribution of resources especially in rural areas continued to impact the healthcare system as these were intrinsically tied to economic policies and infrastructure development (Sopitshi and Van Niekerk, n.d:7). Thus, the pandemic could only strain the already overburdened health system in the country. In this regard, the Church umbrella bodies used their structures and networks to navigate through the pandemic. This implied that the public health education efforts in the context of the pandemic were conveyed given the wide presence of the Church in various parts of the country, both urban and rural, pointing to the strength shared by faith communities in public health centred on their widespread presence (ARHAP, 2005). The 
Church umbrella bodies also used their network to provide practical interventions during the pandemic. Closely related to their religious behaviour centred on theologies of compassion, these responses also demonstrated the trust and authority associated with the religious leaders. In this way, religion was positively used to contribute towards the fight against the pandemic in ways that revealed how the Church umbrella bodies stood together in faith to fight the COVID-19 pandemic.

\section{Suggestions on religion's place in a pandemic}

The responses of the Church umbrella bodies ultimately pointed to a collaborative relationship between the church and state during the pandemic with isolated moments of disagreement on the course of action. The voice of the Church umbrella bodies remained significant during the crisis as affirmed by Marshall (2020) that people tend to look more to religious authorities for guidance on how to behave and what to believe during a crisis. This brings to the fore lessons which include the need to safeguard and promote human life, as both the church and state exist to serve humanity; and need to recognise and appreciate the vital roles of religious actors during pandemics so as to draw on religious ideas and behaviour since cultural and religious practices are very often crucial in curbing the spread of pandemics; and incorporating faith leaders in emergency response teams during pandemics.

Given the largely positive utilisation of religion as a resource during the pandemic, the chapter points to suggestions centred on the religious teachings, practices, organisation and experiences. In relation to religious teachings and practices, the chapter suggests the continued use of scripture to draw lessons on how pandemics ought to be managed and reorienting rituals in ways which promote life. This is deemed significant as existing studies have affirmed that when exposed to a threat such as a pandemic, people resort to various strategies of survival, faith being one of them, which allows them to keep hope and feel a sense of security (Kowalczyk et al. 2020).

Since religious leaders were a trusted source of information in the country, with a presence in every part of the country, the chapter suggests continued capacity building of religious leaders and utilising their structures to foster the communication of vital information and facts on the pandemic across the country. Religious leaders were long standing partners in public health as the church has been effective in reaching the most destitute in the country (Mwale, 2013). Given the vast experiences of the Church in public health, the chapter suggests the recognition of religious leaders as critical players in a crisis as they are the bridge between science and spirituality in the context of the pandemic. As affirmed by Hart and Koenig (2020), religious faith will likely make an important difference in how many make it through this challenging time in the history of nations and the world. 


\section{Conclusion}

The chapter explored the place of religion during a pandemic using the responses of the Church umbrella bodies to the COVID-19 pandemic in Zambia. Given that the Church umbrella bodies utilised their teachings, networks (structures), religious behaviours and experiences to respond to COVID-19, the chapter concludes that the response of Church umbrella bodies showed that constructive use of religion could be instrumental during pandemics. This implied that efforts of preventing and managing pandemics needed to embrace religious actors for effective and far-reaching responses to public health. The chapter also concludes that religious actors remained key stakeholders in public health since the response of the Church umbrella bodies demonstrated how religion could be mobilised as a tool to navigate through a pandemic and thus contribute to the promotion of life.

\section{References}

African Religious Health Assets Programme (ARHAP). 2005. Background and a Conceptual Framework for Contributors, in An Invitation: International Case Study Colloquium, by ARHAP, Pretoria, South Africa, 13-16 July: 1-3.

Aluko, Oluwasegun Peter. 2020. COVID-19 Pandemic in Nigeria: The Response of the Christian Church. African Journal of Biology and Medical Research 3(2):111-125.

Barker, Chris, Nancy Pistrang, and Robert Elliott. 2002. Research Methods in Clinical Psychology: An Introduction for Students and Practitioners. England: John Wiley and Sons.

Barnett, Tony, and Alan Whiteside. 2002. AIDS in the Twenty-First Century: Disease and Globalization. New York: Palgrave Macmillan.

Becket, Adam. 2018. 'Cholera Epidemic in Zambia Shuts Churches.' Church Times. 19th January.

Braley, Matthew Bersagel. 2017. Recovering Religion: Practising Intersectoral Cooperation in a Time of Cholera. Development in Practice 27(5): 745-749.

Braun, Virginia, and Victoria Clarke. 2006. Using Thematic Analysis in Psychology. Journal of Qualitative Research in Psychology 3: 77-101.

Cahill, Lisa Sowle. 2007. Global Health and Catholic Social Commitment. Health Progress 88(3):55-59.

Chitando, Ezra. 2007. Living with Hope: African Churches and HIVIAIDS 1. Geneva: WCC.

Church Mother Bodies. 2020. Statement by the Church Mother Bodies on the Coronavirus Disease - COVID-19 Pandemic. 28th March.

Deguma, Jabin J., Melona C. Deguma, Jemima N. Tandag, and Harlene Marie B. Acebes. 2020. Where Is the Church in the Time of COVID-19 Pandemic: Preferring the Poor via G. Gutierrez' 'Liberation' and the Catholic Church's Social Teaching in the Philippine Setting. Journal of Social and Political Sciences 3(2): 363-374.

del Castillo, Fides A., Hazel T. Biana, and Jeremiah Joven B. Joaquin. 2020. ChurchInAction: The Role of Religious Interventions in Times of COVID-19. Journal of Public Health 42(3): 633-634. 
Dibeela, P. Moiseraela. 2007. Module 6: A Theology of Life in The HIV \& AIDS Context, in Theology in the HIV \& AIDS Era Series, edited by M. W. Dube. Geneva: WCC.

Dube, Musa W. 2007. Module 7: A Theology of Compassion in the HIV \& AIDS Era, in Theology in the HIV \& AIDS Era Series, edited by M. W. Dube. Geneva: WCC.

Featherstone, Andy. 2015. Keeping the Faith: The Role of Faith Leaders in the Ebola Response. London: $C A F O D$.

Hackett, Rosalind, Anne Melice, Steven Van Wolputte, and Katrien Pype. 2014. Interview: Rosalind Hackett Reflects on Religious Media in Africa. Social Compass 61(1): 67-72.

Hadebe, M. Nontando. 2007. Module 8: A Theology of Healing in the HIV \& AIDS Era, in Theology in the HIV \& AIDS Era Series, edited by M. W. Dube. Geneva: WCC.

Hart, Curtis. W., and Koenig, Harold. G. 2020. Religion and Health During the COVID-19 Pandemic. Journal of Religion and Health 59: 1141-1143.

Hinfelaar, Hugo. 2004. History of the Catholic Church in Zambia:1895-1995. Lusaka: Bookworld Publications.

http://www.fides.org/en/news/67770 AFRICA_ZAMBIA_A_Church_fund_to_ fight_Covid_19_the_solidarity_of_the_Bishops_of_Malawi_Zambia_and_Zimbabwe

https://www.oikoumene.org/en/press-centre/news/knowing-covid-19-was-on-itsway-africas-churches-prepared

https://www.who.int/csr/don/11-december-2017-cholera-zambia/en/

Iannaccone, Laurence R. 1990. Religious Practice: A Human Capital Approach. Journal for the Scientific Study of Religion 29: 297-314.

Iyakaremye, Innocent. 2015. Neglecting Religious Health Assets in Responding to HIV and AIDS. An Assessment of the Response of the Free Methodist Church of Southern Africa to HIV and AIDS. Missionalia 43(1): 23-44.

Jaja, Ishmael Festus, Madubuike Umunna Anyanwu, and Chinwe-Juliana Iwu Jaja. 2020. Social Distancing: How Religion, Culture and Burial Ceremony Undermine the Effort to Curb COVID-19 in South Africa. Emerging Microbes \& Infections 9(1): 1077-1079.

Jansen, Perry. 2019. The Role of Faith-Based Organizations and Faith Leaders in the 2014-2016 Ebola Epidemic in Liberia. Christian Journal for Global Health 6(1): $70-78$.

Kothari, Chakravanti Rajagopalachari. 2004. Research Methodology: Methods and Techniques. New Delhi: New Age International.

Kowalczyk, Oliwia, Roszkowski, Krzysztof, Montane, Xavier, Pawliszak, Wojciech, Tylkowski, Bartosz and Bajek, Anna. 2020. Religion and Faith Perception in a Pandemic of COVID-19. Journal of Religion and Health 59(6): 2671-2677.

Lichtenstein, Amanda, Rosemary Ajayi, and Nwachukwu Egbunike. 2020. Across Africa, COVID-19 Heightens Tension Between Faith and Science. Pandemic Response and Religion in the USA: Doctrine 1.

Marshall, Katherine, and Sally Smith. 2015. Religion and Ebola: Learning from Experience. The Lancet 386(10005): e24-e25.

Mendoza, Ruben C. 2020. What If: COVID-19 in the Philippines in the Light of the Catholic Social Tradition. Journal of Dharma 45(2): 201-222.

Ministry of Health. 2020a. Ministerial Update: Press Briefing on COVID-19 and Additional Preventive and Control Measures, 17 March, Lusaka. 
Mukuka, Mwenya. 2020. Church Mother Bodies Come Together in Support of Government Amid COVID-19. AMECEA News, 3 April.

Muzaffar, C Chandra. 2005. Religious Conflict in Asia: Probing the Causes, Seeking Solutions, in Bridge or Barrier: Religion, Violence and Visions for Peace, edited by G. Haar ter and J.J. Busuttil. Leiden: Brill: 57--79.

Mwale, Nelly. 2013. Religion and Development in Zambia: The Role of the Roman Catholic Church in the Political Development of Zambia 1890-1964. Interdisciplinary Journal for the Study of the Arts and Humanities in Southern Africa (Alternation) 1: 110-133.

Mwale, Nelly and Chita, Joseph. 2020. The Catholic Church and Epidemics: Safeguarding People's Wellbeing in the Advent of the 2017/18 Cholera Outbreak in Zambia. Alternation Special Edition 30: 295-310.

Mulenga, Eddie M., and José M. Marbán. 2020. Is COVID-19 the Gateway for Digital Learning in Mathematics Education? Contemporary Educational Technology 12, 2: ep269. https://doi.org/10.30935/cedtech/7949

Ncube, Sipilisiwe. 2020. Mother Church bodies SHAME Government over Prime TV Closure. News Diggers, 7 March.

O'Brien, David. J., and Shannon, Thomas. A. 1992. Catholic Social Thought: The Documentary Heritage. Maryknoll: Orbis Books.

Olivier, Jill. 2011. Religion and Policy on HIV and AIDS: A Rapidly Shifting Landscape, in Religion and HIV and AIDS: Charting the Terrain, edited by B. Haddad. Scottsville: University of KwaZulu-Natal Press: 81-104.

Olivier, Jill, and Gillian Margaret Paterson. 2011. Religion and Medicine in the Context of HIV and AIDS: A Landscaping Review, in Religion and HIV and AIDS: Charting the Terrain, edited by B. Haddad. Scottsville: University of KwaZuluNatal Press: 25-51.

Phiri, Isaac. 1999. Why African Churches Preach Politics: The Case of Zambia. Journal of Church \& State 41: 323-347.

Sintema, Edgar John. 2020. Effect of COVID-19 on the performance of Grade 12 students: Implications for STEM Education. Eurasia Journal of Mathematics, Science and Technology Education 16, 7: em1851. https://doi.org/10.29333/ ejmste/7893

Ter Haar, Gerrie. 2005. Religion: Source of Conflict or Resource for Peace?. Bridge or Barrier: Religion, Violence and Visions for Peace. Leiden: Brill, 303-320.

UN Office for the Coordination of Humanitarian Affairs. 2020. Zambia Situation Report. 29 July.

Verter, Bradford. 2003. Spiritual Capital: Theorising Religion with Bourdieu against Bourdieu.' Sociological Theory 21(2), 150-174.

Wigglesworth, Alex. 2020. More Coronavirus Cases Linked to California Church Services. Los Angeles Times, 24 May.

Wildman, Wesley J., Joseph Bulbulia, Richard Sosis, and Uffe Schjoedt. 2020. Religion and the COVID-19 Pandemic. Religion, Brain \& Behaviour 10(2): 115-117.

Zambia Conference of Catholic Bishops. (2016). Strategic Plan 2017-2026. ZCCB: Lusaka.

Zambia Conference of Catholic Bishops. (2020). Memo: Extension of the suspension of Church gatherings and Liturgical Celebrations in View of the Continued Fight against COVID-19. 25 April. 